\title{
Ecological and health risk assessment of potentially toxic elements in Ewaso Nyiro River surface water, Kenya
}

\author{
Samwel Maina Njuguna ${ }^{1,2,3} \cdot$ Kelvin Babu Githaiga ${ }^{1,2,3}$. Janet Atieno Onyango ${ }^{1,2,3} \cdot$ Robert Wahiti Gituru ${ }^{2,4}$. \\ Xue Yan ${ }^{1,2,3}$
}

Received: 17 October 2020 / Accepted: 22 December 2020 / Published online: 18 January 2021

(c) The Author(s) 2021 OPEN

\begin{abstract}
Ewaso Nyiro basin covers an area of about $210,226 \mathrm{~km}^{2}, 36.3 \%$, of Kenya drainage area and bears $5.8 \%$ of Kenya water potential with an annual yield of 1469 million $\mathrm{m}^{3}$. The river is the principal source of domestic and irrigation water to the arid north of Kenya. To determine metal and nutrient concentration of Ewaso Nyiro River surface water, a total of 30 water samples, 15 samples each for dry (February) and wet (August) seasons of 2019, were collected. Chromium, lead, iron, manganese, cobalt, cadmium, mercury, selenium, molybdenum, boron, copper, zinc, arsenic, nickel, aluminum, total phosphorus and nitrate were analyzed in the two seasons. Ecological risk assessment was determined by calculating contamination factor, pollution load index and ecological risk index. Multivariate statistical analysis was used to infer pollutants association and identify their potential sources. Cadmium, arsenic, lead, molybdenum, mercury, selenium and nickel were not detected in both seasons, while manganese, iron and aluminum were the main pollutants identified. Ewaso Nyiro irrigation water had a manganese contamination factor of 9.17, implying it was very contaminated. Twenty-seven and $40 \%$ of sampled sites in dry and wet seasons, respectively, had more than $0.3 \mathrm{mg} / \mathrm{L}$ of iron that is recommended by USEPA in drinking water. Herbicides, leached fertilizer and fuel leaking into the river water were the primary sources of anthropogenic pollution.
\end{abstract}

Keywords Ewaso Nyiro $\cdot$ Risk assessment $\cdot$ Water quality $\cdot$ Nutrients $\cdot$ Heavy metals

\section{Introduction}

Water is an indispensable resource. It is used in agricultural production, domestic use and industrial activities since it is a universal solvent. Global freshwater distribution is uneven with some regions facing severe scarcity while others enjoying surplus [16]. It is estimated 4 billion people, more than half of global population, face severe water shortage at least one month in a year [4]. Water scarcity has resulted in regional and local conflicts $[25,29]$. Kenya is a case in point. Over a hundred people perished due to conflicts between herders and farmers in 2012 [1]. Water scarcity is a consequence of rapid population growth and changing weather patterns that are associated with erratic precipitation and prolonged droughts $[5,18]$.

Immense pressure on water resources has resulted in pollution, jeopardizing human health [37]. Contaminated water causes over 5 million annual deaths worldwide [36].

Polluted water-related health complications are widespread and are not confined to developing countries, due to bioaccumulation and biomagnification in the food chain [2]. Incidences of ecological risk caused by zinc have been observed in Japan [30]. Irrigation water polluted with heavy metals contaminates crops under cultivation and

$\triangle$ Xue Yan, yanx@wbgcas.cn | ${ }^{1}$ Wuhan Botanical Garden, Chinese Academy of Sciences, Key Laboratory of Aquatic Botany and Watershed Ecology, Wuhan 430074, China. ${ }^{2}$ Sino-Africa Joint Research Center, Chinese Academy of Sciences, Wuhan 430074, China. ${ }^{3}$ University of Chinese Academy of Sciences, Beijing 100049, China. ${ }^{4}$ Jomo Kenyatta University of Agriculture and Technology, Juja, Kenya. 
poses risk to human health. Similarly, consumption of fish from polluted aquatic ecosystems may be a health threat [10].

High concentration of iron in drinking water has been reported to cause muscle crumps, severe constipation, headache, gastric ulcers, malignant tumor and even rapid heart pulses in some instances $[9,33]$.

Kenya is classified as a water scarce country with $80 \%$ of land mass being arid and semiarid [33]. Majority of the population is concentrated in areas with adequate rainfall for agriculture, and vast areas are sparsely populated with nomadic pastoralists. Meager water resources that are available are heavily polluted with potentially toxic elements. High concentration of $\mathrm{As}, \mathrm{Hg}, \mathrm{Ni}, \mathrm{Cu}$ and $\mathrm{Cd}$ was detected in lakes Bogoria and Elementaita [48]. Similarly, high levels of $\mathrm{Mn}$, Fe and $\mathrm{Al}$ have been reported in Tana River [31].

Majority of Kenyan population is poor with limited access to improved drinking water [12]. Domestic use of polluted water is thus highly likely, and this may predispose innocent and poor people to deleterious effects of potentially toxic elements.

Regular monitoring of water sources used for domestic purposes is therefore paramount to safeguard human health. Previous documented studies of Ewaso Nyiro were based on water management, scarcity and conflicts [22, 41]. The current study was conducted to (1) determine heavy metal and nutrient concentration in surface water of Ewaso Nyiro River, (2) assess probable sources of heavy metals and nutrients pollution, (3) evaluate whether Ewaso Nyiro River is under ecological risk and (4) determine whether domestic, irrigation and livestock use of Ewaso Nyiro River surface water poses any health risk to consumers.

\section{Materials and methods}

\subsection{Study area}

Ewaso Nyiro basin constitutes $36.3 \%$ of Kenya drainage basin and originates from Aberdare Ranges and Mount Kenya [34]. The basin covers $210,226 \mathrm{~km}^{2}$, bearing $5.8 \%$ of Kenya water potential, and has an average annual rainfall of $411 \mathrm{~mm}$ and 1469 million $\mathrm{m}^{3}$ annual yield $[19,49]$. Main tributaries draining into Ewaso Nyiro include, Nanyuki, Timau, Rongai, Burguret, Segera, Naromoru, Engare, Moyak, Ewaso Narok, Pesi and Ngobit rivers [21]. Ewaso Nyiro River and its tributaries traverse Nyeri, Nyandarua and Laikipia counties before draining into Lorian Swamp, $2918 \mathrm{~km}^{2}$, at Merti in Isiolo County.

Ewaso Nyiro drainage basin population has increased rapidly in recent past. For instance, Laikipia County population has tripled over the last three decades from 134,524 in 1979 to 399,227 in 2009 [22]. The upper reach has a population density of 100 people per $\mathrm{km}^{2}$ and about 10 in the lower reaches that are arid and semiarid [8].

Water resources in the upper reach of the basin have been under immense pressure resulting in intermittent flow of Ewaso Nyiro below Archers Post [20].

Main economic activities in Ewaso Nyiro basin include large- and small-scale horticulture crops production in the upper reaches and livestock rearing downstream of the basin. The main challenges undermining Ewaso Nyiro ecosystem are catchment degradation, increased irrigation demand and groundwater salinity and saline intrusion [6].

Water sampling sites were distributed around the catchment and middle reaches up to Archers post since lower reaches had dried during the dry season. Sampling sites selection was based on land use pattern, economic activities and areas suspected to experience point source pollution.

\subsection{Water sampling}

A total of 30 samples were collected during wet and dry seasons, as shown in Fig. 1, 15 samples for each season. Sampling in dry season was conducted in late February, while wet season samples were collected in August of 2019. Ewaso Nyiro River is shallow with homogeneous vertical water column. Sampling was done $15 \mathrm{~cm}$ below water surface using precleaned one-liter polyethylene bottles. Samples were later taken to the laboratory where they were filtered using $0.45-\mu \mathrm{m}$ cellulose acetate membrane filter, acidified with nitric acid to $\mathrm{pH}>2$ and refrigerated at $4{ }^{\circ} \mathrm{C}$ before commencement of the analysis.

\subsection{Sample analysis and quality assurance}

Analysis to determine concentration of heavy metals in water was determined using inductively coupled plasma-optical emission spectrometry, ICP-OES (5100, Agilent Technologies), while nitrate $\left(\mathrm{NO}_{3}{ }^{-}\right)$was determined by calorimetric method. Total phosphorus (TP) and iron $(\mathrm{Fe})$ were determined by spectrometric method (UV1700 , Pharmaspec, Shimadzu) at an absorbance of 880 and $515 \mathrm{~nm}$, respectively.

To ensure analytical integrity and quality of the results were of acceptable level, blanks and sample replicates were randomly analyzed and had to tally to validate results. Standard reference material (CROP-1-REV1 obtained from Inorganic Ventures, USA) was used for quality control (one blank and one standard sample for each 20 samples). Method efficiency was determined by 


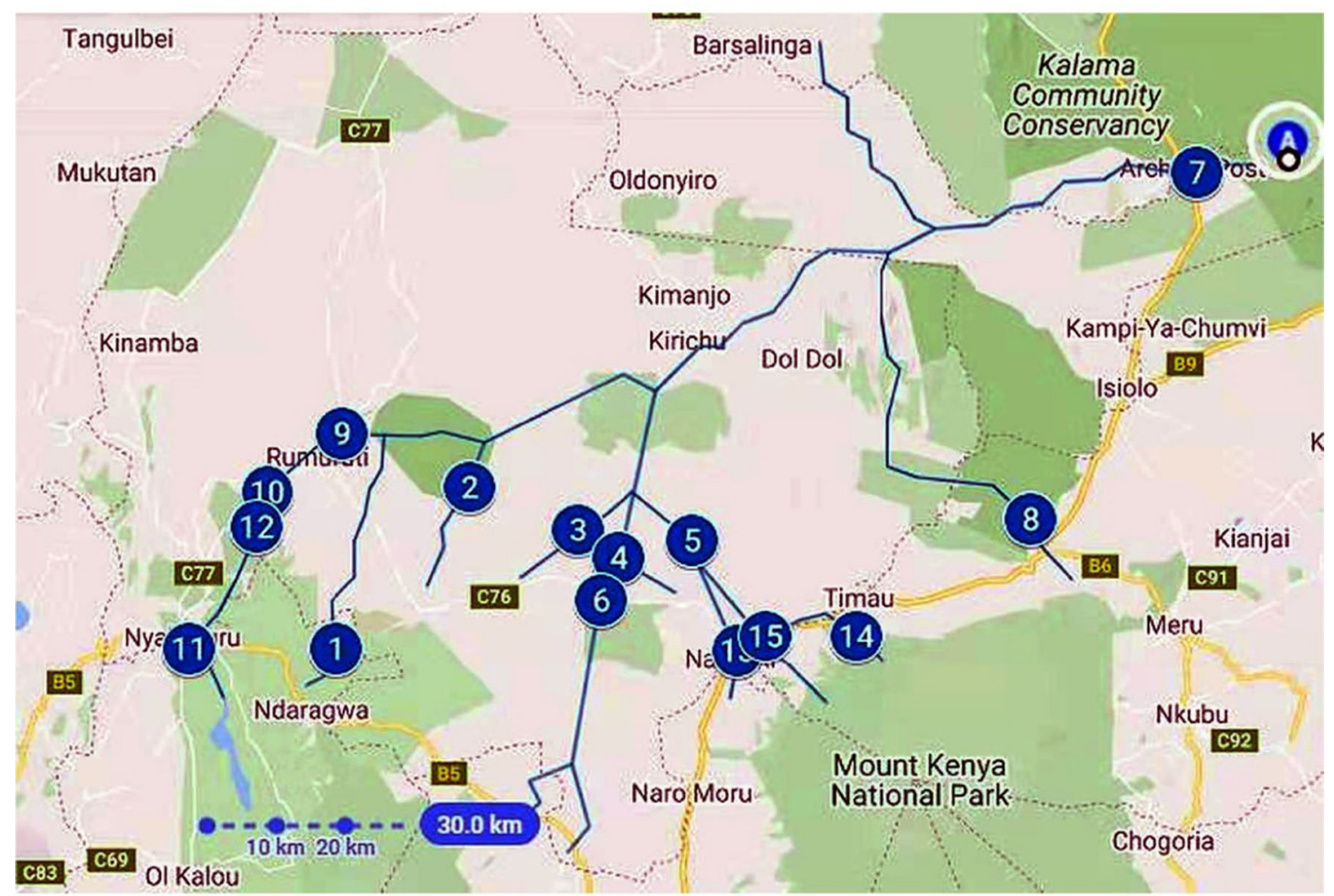

Fig. 1 Map of the sampling points

the use of recovery rates that ranged between 89 and $104 \%$. Relative standard deviation from seven samples was applied to generate minimum detection limits (MDL) that were as follows: $\mathrm{Cd}=0.002 \mathrm{mg} / \mathrm{L}, \mathrm{Cr}=0.004 \mathrm{mg} / \mathrm{L}$, $\mathrm{Pb}=0.009 \mathrm{mg} / \mathrm{L}, \mathrm{As}=0.007 \mathrm{mg} / \mathrm{L}, \mathrm{Ni}=0.003 \mathrm{mg} / \mathrm{L}$, $\mathrm{Hg}=0.001 \mathrm{mg} / \mathrm{L}, B=0.01 \mathrm{mg} / \mathrm{L}, \mathrm{Cu}=0.01 \mathrm{mg} / \mathrm{L}$, $\mathrm{Se}=0.02 \mathrm{mg} / \mathrm{L}, \mathrm{Al}=1.5 \mathrm{mg} / \mathrm{L} \mathrm{NO}_{3}{ }^{-}=0.01 \mathrm{mg} / \mathrm{L}$ and $\mathrm{P}=0.1 \mathrm{mg} / \mathrm{L}$.

Data were analyzed using SPSS (version 21), while map was prepared using Google maps.

\subsection{Determination of pollution and ecological risk indicators}

\subsubsection{Contamination factor (CF)}

Contamination factor is used to express the level of concentration of an element in a sample compared to preindustrial reference value. The current research has employed recommended concentration in human and livestock drinking and irrigation water as reference values. Contamination factor is used as a measure of potential toxicity, as shown in Eq. 1 [27].
$\mathrm{CF}=C_{\text {metal }} / C_{\text {reference }}$

The CF values were classified into six categories, as given in Table 1, as recommended by Hakanson [40].

\subsubsection{Pollution load index (PLI)}

The PLI which is an integrated tool for determining pollution of a certain group of pollutants (metals) was also applied, as indicated in Eq. 2 [43].

$\mathrm{PLI}=\left(\mathrm{CF}_{1} X \mathrm{CF}_{2} X \mathrm{CF}_{3} X \ldots X \mathrm{CF}_{n}\right) 1 / n$

where $\mathrm{CF}$ is the contamination factor for individual metals and $\mathrm{n}$ is the number of pollutants (metals). The PLI values are classified into four categories, as given in Table 1.

\subsubsection{Ecological risk (ER)}

The ER is used to assess degree of environmental damage or probability of ecosystems experiencing detrimental ecological effects from pollutants [51].

Ecological risk was determined as recommended by Hakanson, as given in Eq. 3 [23]. 
Table 1 Risk assessment

\begin{tabular}{llll}
\hline Risk assessment & Level & Values & Assessment index \\
\hline Contamination factor & 1 & CF $<1$ & Low contamination factor \\
& 2 & $1 \leq \mathrm{CF}<3$ & Moderate contamination factor \\
& 3 & $3 \leq \mathrm{CF}<6$ & Considerable contamination factor \\
Pollution load index & 4 & $\mathrm{CF} \geq 6$ & Very high contamination factor \\
& 1 & $\mathrm{PLI} \leq 1$ & Uncontaminated by heavy meals \\
Ecological risk & 2 & $\mathrm{PLI}>1$ & Contaminated by heavy metals \\
& 1 & $<10$ & No damage \\
& 2 & $10-40$ & Mild damage \\
& 3 & $40-80$ & Moderate damage \\
& 4 & $80-160$ & High damage \\
& 5 & $160-320$ & Serious damage \\
& 6 & $>320$ & Extreme damage \\
& 1 & $<50$ & No risk \\
& 2 & $50-100$ & Mild risk \\
& 3 & $150-300$ & Moderate risk \\
& 4 & $300-600$ & High risk \\
& 5 & $600-1200$ & Serious risk \\
& 6 & $>1200$ & Extreme risk \\
\hline
\end{tabular}

$\mathrm{ER}=T_{i} \times \mathrm{CF}$

where $T_{i}$ is the potential ecological risk coefficient. Potential ecological risk coefficient for $\mathrm{Cu}, \mathrm{Zn}, \mathrm{As}, \mathrm{Cd}, \mathrm{Cr}, \mathrm{Pb}, \mathrm{Ni}$, $\mathrm{Hg}, \mathrm{Mn}$ and $\mathrm{Co}$ is 5, 1, 10, 30, 2, 5, 5, 40, 1 and 5, respectively
[46]. The ER values are grouped into six categories as shown in Table 1.

Table 2 Descriptive statistics of potentially toxic elements and nutrients in Ewaso Nyiro River water against WHO drinking water guidelines $(\mathrm{mg} / \mathrm{L})$

\begin{tabular}{|c|c|c|c|c|c|c|c|c|c|c|c|}
\hline \multirow{2}{*}{$\begin{array}{l}\text { Potentially toxic ele- } \\
\text { ments and nutrients }\end{array}$} & \multicolumn{5}{|c|}{ Wet season } & \multicolumn{6}{|c|}{ Dry season } \\
\hline & Min & Max & Mean & Med & Std. deviation & Min & Max & Mean & Med & Std. deviation & WHO \\
\hline $\mathrm{NO}_{3}^{-}$ & 0 & 2.23 & 0.53 & 0.27 & 0.72 & 0 & 1.96 & 0.29 & 0.1 & 0.5 & 50 \\
\hline $\mathrm{TP}$ & 0 & 0.46 & 0.13 & 0 & 0.18 & 0 & 0.29 & 0.07 & 0 & 0.09 & 0 \\
\hline B & 0 & 0.04 & 0.01 & 0 & 0.01 & 0 & 0.05 & 0.01 & 0 & 0.02 & 0.5 \\
\hline $\mathrm{Cu}$ & 0 & 0.04 & 0 & 0 & 0.01 & 0 & 0.01 & 0 & 0 & 0 & 2 \\
\hline $\mathrm{Zn}$ & 0 & 0.1 & 0.02 & 0 & 0.03 & 0 & 0.07 & 0.01 & 0 & 0.02 & 3 \\
\hline As & - & - & - & - & - & - & - & - & - & - & 0.01 \\
\hline $\mathrm{Cd}$ & - & - & - & - & - & - & - & - & - & - & 0.003 \\
\hline $\mathrm{Cr}$ & 0 & 0.017 & 0 & 0 & 0 & - & - & - & - & - & 0.05 \\
\hline $\mathrm{Pb}$ & - & - & - & - & - & 0 & 0.05 & 0 & 0 & 0.01 & 0.001 \\
\hline $\mathrm{Ni}$ & - & - & - & - & - & - & - & - & - & - & 0.07 \\
\hline $\mathrm{Hg}$ & - & - & - & - & - & - & - & - & - & - & 0.006 \\
\hline $\mathrm{Se}$ & - & - & - & - & - & - & - & - & - & - & 0.01 \\
\hline Al & 0.11 & 22.5 & 3.88 & 0.51 & 7.33 & 0.14 & 16.9 & 1.96 & 0.43 & 4.16 & 0.2 \\
\hline $\mathrm{Fe}$ & 0.17 & 16.1 & 3.34 & 0.85 & 4.5 & 0.2 & 15.6 & 2.69 & 0.94 & 4.27 & 0 \\
\hline $\mathrm{Mn}$ & 0.01 & 4.5 & 0.79 & 0.24 & 1.32 & 0.02 & 2.04 & 0.35 & 0.14 & 0.67 & 0.4 \\
\hline Mo & - & - & - & - & - & - & - & - & - & - & 0.07 \\
\hline Co & 0 & 0.04 & 0 & 0 & 0.01 & - & - & - & - & - & 0.05 \\
\hline
\end{tabular}

Reference: [13] 


\section{Results and discussion}

\subsection{Heavy metals and nutrient concentration in water}

There was a significant difference in concentration of pollutants in different sites and seasons as indicated in Table 2. Mean concentration of all detected pollutants, with exception of $B$, was higher in wet season compared to dry season. Only $\mathrm{Al}, \mathrm{Fe}$ and $\mathrm{Mn}$ were detected in all sampled sites in the two seasons. As, $\mathrm{Cd}, \mathrm{Hg}, \mathrm{Pb}, \mathrm{Ni}$ and Se were below detection limit in all sites in both seasons. Aluminum recorded the highest concentration in both seasons recording 22.5 and $16.90 \mathrm{mg} / \mathrm{L}$ in wet and dry seasons, respectively. Although World Health Organization (WHO) has not given maximum concentration of $\mathrm{Al}$ in drinking water, concentration above $0.2 \mathrm{mg} / \mathrm{L}$ is not acceptable to most consumers [13]. Eighty-seven percent and $67 \%$ of all sampled sites had more than $0.2 \mathrm{mg} / \mathrm{L}$ of
$\mathrm{Al}$ in wet and dry seasons, respectively. Cobalt, $\mathrm{Mn}$ and Fe above WHO recommended drinking water guidelines were detected in one site for $\mathrm{Co}$, three sites for $\mathrm{Mn}$ and six sites for Fe in wet season. Similarly, exceedingly high concentration of $\mathrm{Mn}$ and Fe was registered in three sites for $\mathrm{Mn}$ and four sites for Fe in the dry season. Median concentration of Fe in the two seasons was above, $0.3 \mathrm{mg} / \mathrm{L}$, which may stain laundry and plumbing fixtures besides exceeding USEPA drinking water guideline [13], Njuguna et al. [33]. Majority of the sampled sites had relatively low concentration of $\mathrm{NO}_{3}{ }^{-}$registering a median of 0.27 and $0.10 \mathrm{mg} / \mathrm{L}$, in wet and dry seasons, respectively. Although TP maximum concentration in both seasons was above $0.2 \mathrm{mg} / \mathrm{L}$ and likely to cause eutrophication, median concentration was below detection limit. High concentration of $\mathrm{Al}$, Fe and $\mathrm{Mn}$ has been recorded in other water bodies in Kenya. Aluminum and $\mathrm{Mn}$ concentrations of 8.96 and $1.11 \mathrm{mg} / \mathrm{L}$, respectively, were detected in Tana River surface water in 2018 [31]. Similarly, Fe and Mn, 3.26 and 0.98 mg/L, respectively, were registered in Sasumua reservoir that supplies
Table 3 Potentially toxic elements concentration, contamination factor (CF), ecological risk (ER), pollution load index (PLI) and risk index (RI) for human and livestock drinking and irrigation use $(\mathrm{mg} / \mathrm{L})$

\begin{tabular}{|c|c|c|c|c|c|c|c|c|c|}
\hline & Mean & $\begin{array}{l}\text { Human } \\
\text { drinking } \\
\text { water }\end{array}$ & $\mathrm{CF}$ & ER & $\begin{array}{l}\text { Livestock } \\
\text { drinking } \\
\text { water }\end{array}$ & $\mathrm{CF}$ & ER & Irrigation water & $\mathrm{CF}$ \\
\hline \multicolumn{10}{|c|}{ Dry season } \\
\hline B & 0.000 & 0.500 & 0.000 & 0.000 & 5.000 & 0.000 & 0.000 & 0.750 & 0.000 \\
\hline $\mathrm{Cu}$ & 0.001 & 2.000 & 0.000 & 0.002 & 0.500 & 0.000 & 0.002 & 0.200 & 0.004 \\
\hline $\mathrm{Zn}$ & 0.006 & 3.000 & 0.002 & 0.002 & 24.000 & 0.000 & 0.143 & 2.000 & 0.003 \\
\hline As & 0.000 & 0.010 & 0.000 & 0.000 & 0.200 & 0.000 & 0.000 & 0.100 & 0.000 \\
\hline Al & 0.000 & 0.200 & 0.000 & 0.000 & 5.000 & 0.000 & 0.000 & 5.000 & 0.000 \\
\hline $\mathrm{Pb}$ & 0.003 & 0.010 & 0.294 & 0.015 & 0.100 & 0.000 & 0.001 & 5.000 & 0.001 \\
\hline $\mathrm{Fe}$ & 0.000 & 0.300 & 0.000 & 0.000 & - & 0.000 & 0.000 & 5.000 & 0.000 \\
\hline $\mathrm{Ni}$ & 0.000 & 0.070 & 0.000 & 0.000 & 1.000 & 0.000 & 0.000 & 0.200 & 0.000 \\
\hline $\mathrm{Mn}$ & 0.35 & 0.400 & 0.86 & 0.86 & 0.050 & 0.092 & 0.092 & 0.200 & 9.167 \\
\hline Co & 0.000 & 0.050 & 0.000 & 0.000 & 1.000 & 0.000 & 0.000 & 0.050 & 0.000 \\
\hline PLI & & & 0.250 & & & 0.070 & & & \\
\hline $\mathrm{RI}$ & & & 4.602 & & & 0.238 & & & \\
\hline \multicolumn{10}{|c|}{ Wet season } \\
\hline B & 0.009 & 0.500 & 0.018 & 0.000 & 5.000 & 0.002 & 0.000 & 0.750 & 0.012 \\
\hline $\mathrm{Cu}$ & 0.005 & 2.000 & 0.002 & 0.012 & 0.500 & 0.009 & 0.047 & 0.200 & 0.023 \\
\hline $\mathrm{Zn}$ & 0.017 & 3.000 & 0.006 & 0.000 & 24.000 & 0.001 & 0.001 & 2.000 & 0.008 \\
\hline As & 0.000 & 0.010 & 0.000 & 0.000 & 0.200 & 0.000 & 0.000 & 0.100 & 0.000 \\
\hline Al & 3.877 & 0.200 & 19.387 & 0.000 & 5.000 & 0.775 & 0.000 & 5.000 & 0.775 \\
\hline $\mathrm{Pb}$ & 0.000 & 0.010 & 0.000 & 0.000 & 0.100 & 0.000 & 0.000 & 5.000 & 0.000 \\
\hline $\mathrm{Fe}$ & 3.343 & 0.300 & 11.142 & 0.000 & 1.000 & 3.343 & 0.000 & 5.000 & 0.669 \\
\hline $\mathrm{Ni}$ & 0.000 & 0.070 & 0.000 & 0.000 & 1.000 & 0.000 & 0.000 & 0.200 & 0.000 \\
\hline $\mathrm{Mn}$ & 0.791 & 0.400 & 1.978 & 1.978 & 0.050 & 15.823 & 15.823 & 0.200 & 3.956 \\
\hline Co & 0.003 & 0.500 & 0.005 & 0.027 & 1.000 & 0.003 & 0.013 & 0.050 & 0.053 \\
\hline PLI & & & 0.240 & & & 0.130 & & & \\
\hline RI & & & 2.020 & & & 15.880 & & & \\
\hline
\end{tabular}

Bold: high concentration

Njuguna et al. [33] and US Environmental Protection Agency [44] 
water to Kenya's capital, Nairobi, besides $2.82 \mathrm{mg} / \mathrm{L}$ of $\mathrm{Mn}$ in Lake Elementaita [28, 35]. Andisol soils that are prevalent in Kenya highlands are rich in Al, Fe and Mn [33].

\subsection{Risk assessment}

Human and livestock drinking water contamination factor was $<1$ for all potentially toxic elements and therefore was in low contamination factor category in dry season, as given in Table 3. However, irrigation water Mn contamination factor was $>6$ and was therefore very contaminated.

River Ewaso Nyiro human drinking water was moderately contaminated with $\mathrm{Mn}$ but very contaminated for livestock consumption and considerably contaminated for irrigation purposes in wet season. Although Al and Fe human drinking water was under very high contamination, only Fe had considerable contamination for livestock consumption. Manganese had moderate contamination for human drinking, considerable contamination for irrigation and very high contamination for livestock consumption in wet season. Only Mn among all potentially toxic elements had potential of causing mild ecological risk.

Pollution load index was $<1$ for human and livestock drinking and irrigation purposes in both dry and wet seasons, implying the water would be considered generally uncontaminated. Highest risk index recorded was 15.88 in livestock drinking water and was way below 50 that can pose mild risk, suggesting there was no risk posed to human and livestock.

Although risk index posed by potentially toxic elements under investigation was negligible, $\mathrm{Al}, \mathrm{Fe}$ and $\mathrm{Mn}$ contamination was very high. High $\mathrm{Mn}$ in drinking and food stuff has been confirmed to cause health complications. High $\mathrm{Mn}$ in drinking water lowers children IQ. A study conducted in Bangladesh indicated children drinking water with high $\mathrm{Mn}$, above $400 \mu \mathrm{g} / \mathrm{L}$, scored $6.4 \%$ lower in mathematics compared to those whose drinking water had lower or no Mn [17]. Manganese has been noted to replace metabolic role of calcium and may accumulate in bone tissue weakening the bones besides causing adverse effects to the lung, liver and cardiovascular system [3,9]. Aluminum concentration above $0.2 \mathrm{mg} / \mathrm{L}$ is not acceptable to most consumers, based on aesthetic considerations, besides increased number of studies associating high concentration $\mathrm{Al}$ in drinking water with Parkinson and Alzheimer's disease $[9,13]$. High concentration of Fe in drinking water on the other hand is associated with malignant tumor and causes persistence of hepatitis B and C besides being linked to kidney, lung, liver and stomach cancers [18]. Cancer is the third leading cause of death in Kenya after infectious and cardiovascular diseases [26].

Numerous incidences of high $\mathrm{Fe}$ in Kenyan drinking water have been reported. Athi River that serves over four million Kenyans with drinking water recorded a mean of $2.5 \mathrm{mg} / \mathrm{L}$ against USEPA recommended concentration of $0.3 \mathrm{mg} / \mathrm{L}$ [33]. The use of polluted water for livestock and irrigation purposes is unsafe due to bioaccumulation and biomagnification effect in the food chain. Consequently, the use of Ewaso Nyiro River water for livestock and irrigation purposes should be done with caution due to considerable Fe and very high Mn contamination.

\subsection{Multivariate analysis}

Principal component analysis, hierarchical cluster analysis and Pearson correlation were employed to infer pollutants associations and identify their sources.

\subsubsection{Pearson correlation}

Pearson correlation analysis was done among and between heavy metals and nutrients as displayed in Table 4. A strong positive correlation, $p>0.01$, was observed between $\mathrm{Cu}$ and $\mathrm{Cr}, \mathrm{Cu}$ and $\mathrm{Al}$, in wet season. Other significant correlations were between Al-TP, Fe-TP, $\mathrm{B}-\mathrm{Cu}, \mathrm{Cu}-\mathrm{Fe}, \mathrm{Zn}-\mathrm{Fe}, \mathrm{Zn}-\mathrm{Al}, \mathrm{Cr}-\mathrm{Al}, \mathrm{Cr}-\mathrm{Co}$ and $\mathrm{Al}-\mathrm{Fe}$. Strong positive correlation between pollutants indicates a common source, similar behavior or mutual dependence [24]. Aluminum and Fe may have originated from Andisol soils that are common in the study area [31]. Cobalt may have emanated from agrochemicals since it was only detected at site 11, that was under cabbage and garden pea production. Glyphosate that is a common herbicide in Kenya has been noted to contain $\mathrm{Co}$ and $\mathrm{Cr}$ that may dissolve and contaminated aquatic ecosystems [7]. Strong positive correlation observed between $\mathrm{Al}-\mathrm{Cr}$ and $\mathrm{Cr}-\mathrm{Co}$ may imply $C r$ was from both natural and anthropogenic sources since $\mathrm{Al}$ and $\mathrm{Cr}$ are widely distributed in earth crust [13]. Manganese may have been from leaking fuel from irrigation pumps and motor bikes that were being washed in river water since $\mathrm{Mn}$ compounds are used as fuel-oil additives [45]. The highest concentration of $\mathrm{Mn}$ was detected in site 7 where water had been contaminated with oil and sites 11 and 15 where motorbikes were being cleaned in the river.

\subsubsection{Principal component analysis (PCA)}

PCA is a data reduction technique that reduces number of variables to a smaller set of scores called components without losing much of primary data [15]. Varimax rotation was employed in current analysis since variables were presumed to be uncorrelated [33]. Two principal components that explained $80.8 \%$ of total variance were extracted at eigenvalue $>1$ in wet season, as given in Table 5. Component one explained $66 \%$, while component two explained 
Table 4 Pearson correlation matrix of concentration among metals and nutrients in water of the Ewaso Nyiro River

\begin{tabular}{|c|c|c|c|c|c|c|c|c|c|c|c|}
\hline & $\mathrm{TP}$ & $\mathrm{NO}_{3}^{-}$ & B & $\mathrm{Cu}$ & $\mathrm{Zn}$ & $\mathrm{Cr}$ & Al & $\mathrm{Fe}$ & $\mathrm{Mn}$ & Co & $\mathrm{Pb}$ \\
\hline \multicolumn{12}{|c|}{ Wet season } \\
\hline TP & 1 & & & & & & & & & & \\
\hline NO3 & .393 & 1 & & & & & & & & & \\
\hline B & $.583^{\mathrm{b}}$ & -.305 & 1 & & & & & & & & \\
\hline $\mathrm{Cu}$ & $.755^{\mathrm{a}}$ & -.043 & $.838^{\mathrm{a}}$ & 1 & & & & & & & \\
\hline $\mathrm{Zn}$ & $.709^{a}$ & -.109 & $.695^{\mathrm{a}}$ & $.833^{a}$ & 1 & & & & & & \\
\hline $\mathrm{Cr}$ & $.729^{a}$ & .006 & $.785^{\mathrm{a}}$ & $.978^{\mathrm{a}}$ & $.744^{\mathrm{a}}$ & 1 & & & & & \\
\hline $\mathrm{Al}$ & $.828^{\mathrm{a}}$ & .000 & $.797^{a}$ & $.977^{\mathrm{a}}$ & $.853^{\mathrm{a}}$ & $.954^{\mathrm{a}}$ & 1 & & & & \\
\hline $\mathrm{Fe}$ & $.835^{\mathrm{a}}$ & -.074 & $.769^{\mathrm{a}}$ & $.839^{a}$ & $.851^{a}$ & $.753^{\mathrm{a}}$ & $.895^{\mathrm{a}}$ & 1 & & & \\
\hline $\mathrm{Mn}$ & $.581^{\mathrm{b}}$ & -.007 & $.574^{\mathrm{b}}$ & $.654^{\mathrm{a}}$ & .374 & $.731^{\mathrm{a}}$ & $.652^{\mathrm{a}}$ & $.597^{\mathrm{b}}$ & 1 & & \\
\hline Co & $.515^{\mathrm{b}}$ & .127 & .495 & $.725^{\mathrm{a}}$ & .372 & $.853^{a}$ & $.703^{a}$ & .384 & $.776^{\mathrm{a}}$ & 1 & \\
\hline $\mathrm{Pb}$ & - & - & - & - & - & - & - & - & - & - & - \\
\hline \multicolumn{12}{|c|}{ Dry season } \\
\hline TP & 1 & & & & & & & & & & \\
\hline $\mathrm{NO}_{3}^{-}$ & .207 & 1 & & & & & & & & & \\
\hline B & .445 & -.227 & 1 & & & & & & & & \\
\hline $\mathrm{Cu}$ & $.639^{a}$ & .006 & $.596^{\mathrm{b}}$ & 1 & & & & & & & \\
\hline $\mathrm{Zn}$ & $.738^{a}$ & -.038 & $.630^{\mathrm{a}}$ & $.951^{\mathrm{a}}$ & 1 & & & & & & \\
\hline $\mathrm{Cr}$ & - & - & - & - & - & & & & & & \\
\hline $\mathrm{Al}$ & $.778^{\mathrm{a}}$ & -.047 & $.638^{\mathrm{a}}$ & $.958^{\mathrm{a}}$ & $.991^{\mathrm{a}}$ & - & 1 & & & & \\
\hline $\mathrm{Fe}$ & $.843^{\mathrm{a}}$ & -.106 & $.626^{\mathrm{a}}$ & $.830^{\mathrm{a}}$ & $.888^{a}$ & - & $.929^{a}$ & 1 & & & \\
\hline $\mathrm{Mn}$ & -.159 & -.120 & -.134 & -.050 & -.072 & - & -.086 & -.092 & 1 & & \\
\hline Co & - & - & - & - & - & - & - & - & - & - & \\
\hline $\mathrm{Pb}$ & $.639^{a}$ & .006 & $.596^{*}$ & $909^{a}$ & $.951^{\mathrm{a}}$ & - & $.958^{\mathrm{a}}$ & $.830^{\mathrm{a}}$ & -.050 & - & 1 \\
\hline
\end{tabular}

${ }^{a}$ Correlation is significant at the 0.01 level

${ }^{b}$ Correlation is significant at the 0.05 level
Table 5 Rotational component matrix of potentially toxic elements and nutrients in the Ewaso Nyiro River water

\begin{tabular}{|c|c|c|c|c|}
\hline \multirow{2}{*}{$\begin{array}{l}\text { Heavy metal and } \\
\text { nutrients }\end{array}$} & \multicolumn{2}{|c|}{ Wet season } & \multicolumn{2}{|c|}{ Dry season } \\
\hline & PC 1 & PC 2 & PC1 & PC 2 \\
\hline Al & .981 & & .992 & \\
\hline $\mathrm{Cu}$ & .969 & & .952 & \\
\hline $\mathrm{Fe}$ & .916 & & .937 & \\
\hline B & .862 & & .678 & \\
\hline $\mathrm{Zn}$ & .854 & & .976 & \\
\hline TP & .836 & & .815 & \\
\hline $\mathrm{Mn}$ & .739 & & & \\
\hline Co & 695 & & & \\
\hline $\mathrm{NO}_{3}^{-}$ & & .955 & & .960 \\
\hline Eigenvalue & 5.941 & 1.334 & 5.754 & 1.174 \\
\hline Variance \% & 66.006 & 14.825 & 71.924 & 14.670 \\
\hline Cumulative \% & 66.006 & 80.831 & 71.924 & 86.594 \\
\hline
\end{tabular}

$14.8 \%$ of total variance. $\mathrm{Al}, \mathrm{Cu}$ and Fe were in component one and had significant positive loading, $>0.9$. Nitrate was the only variable in component two and had a high loading of 0.96 . Al, $\mathrm{Cu}$ and Fe may have emanated from natural sources. Cases of these elements emanating from natural sources have been reported [39]. Nitrate may have originated from leached fertilizers from agricultural activities.

Dry season had two principal components with components one and two contributing $71.9 \%$ and $14.7 \%$ of total variance, respectively. Component one significant positive loading, >0.9, was from Al, $\mathrm{Cu}, \mathrm{Zn}$ and Fe. Palaeozoic and quaternary sediment that is widespread in Kenya is a major source of Zn, Cu, Al and Fe [11]. Nitrate was the only variable in component two with a high loading of 0.96 and was from leached fertilizers just like in wet season.

\subsubsection{Hierarchical cluster analysis (HCA)}

HCA which is a cluster analysis technique is often coupled with PCA to confirm and validate observed relationships $[47,50]$. Euclidean interval pattern and ward linkage were applied, while potentially toxic element concentrations were standardized using Z-score.

There were four clusters in both wet and dry seasons as indicated in Figs. 2 and 3. Clusters formed were based on element attributes and sources. Cluster $A$ in wet season dendrogram was composed of $\mathrm{Cu}, \mathrm{Cr}$, Al and $\mathrm{B}$. These 
Fig. 2 Hierarchical dendrogram of nutrients and metals in Ewaso Nyiro River during wet season

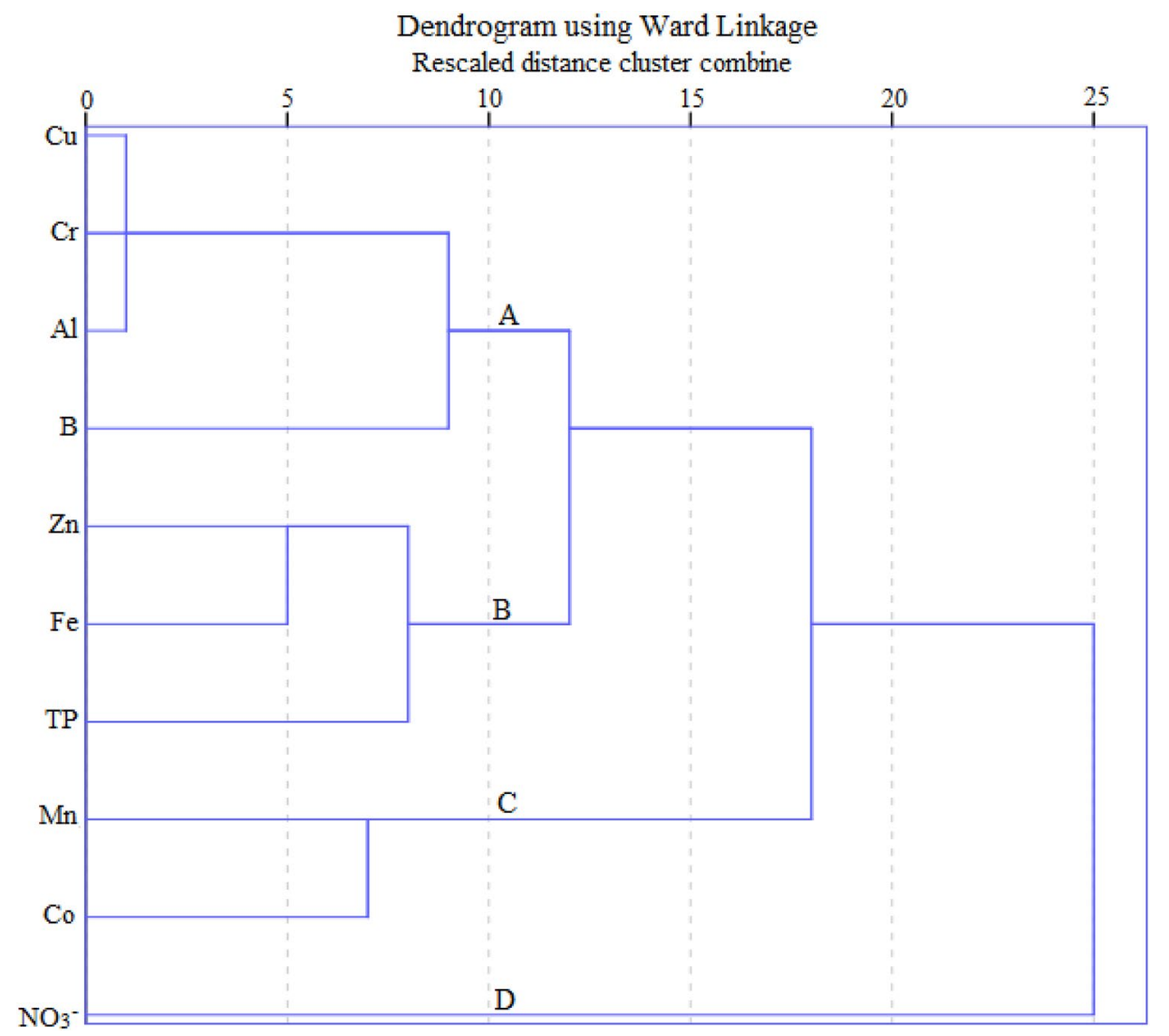

pollutants may be from both anthropogenic and natural sources. Copper and $\mathrm{Cr}$ may be from herbicides, while $\mathrm{Al}$ and $B$ may be from both natural sources and waste water containing $\mathrm{Al}$ used in coagulation and $\mathrm{B}$ from detergents $[7,13,42]$. Custer $B$ was composed of $Z n$, Fe and TP which could be from natural sources. Andisol soils prevalent in study area are rich in Fe, while cases of TP and Zn originating from natural sources have been reported [39]. Cobalt and $\mathrm{Mn}$ were in cluster $\mathrm{C}$ and may have been from herbicides and fuel leaking into the river water. The highest concentrations of $\mathrm{Mn}$ and Co were detected at site 7 that was under agricultural production and was experiencing fuel leak that was contaminating river water. Nitrate was the only pollutant in cluster $D$ and was from leached fertilizer infiltrating into the aquatic ecosystem. Nitrate is readily soluble and may seep from agricultural land and pollute water bodies [13].

Cluster $A$ in dry season dendrogram was composed of $\mathrm{Cu}, \mathrm{Pb}, \mathrm{Zn}, \mathrm{Al}, \mathrm{Fe}$ and $\mathrm{TP}$ and may have originated from natural sources. Lake Olbolosat was the only sampling site with detectable $\mathrm{Pb}$ and also recorded the highest concentration of Zn. Lead is naturally found in soil in low quantities and may emanate from natural weathering of rocks $[10,32]$, while $\mathrm{Zn}$ is relatively mobile and may permeate through soil and end up in river water [38]. Only boron was in cluster $B$ and may have been from anthropogenic sources. The highest concentration of $B$ was detected at Archers Post where people were doing laundry and bathing on river banks. Nitrate and $\mathrm{Mn}$ were the only pollutants in clusters $C$ and $D$, respectively. Nitrate may have been from leached fertilizers, while $\mathrm{Mn}$ may have been from leaking fuel since the highest concentration of $\mathrm{Mn}$ detected was at Rumuruti Swamp where fuel was leaking from irrigation pumps. Rumuruti Swamp is rich in Cyperus papyrus and other beneficial macrophytes such as Cyperus articulatus and Typha latifolia may be introduced to promote phytoremediation of Al and Fe [14, 33].

\section{Conclusion}

There was a significant difference in concentration of potentially toxic elements among different sites. Heavy metals and nutrients were distributed from the catchment to the middle reaches without a properly defined pattern. Dry season had relatively better water quality compared to wet season probably due to river water contamination from runoff. Poor agronomic practices such as the use of Co- and Cu-based herbicides close to riparian zone may have contributed in Ewaso Nyiro River pollution. Leaking irrigation pumps and 
Fig. 3 Hierarchical dendrogram of nutrients and metals in Ewaso Nyiro River during dry season

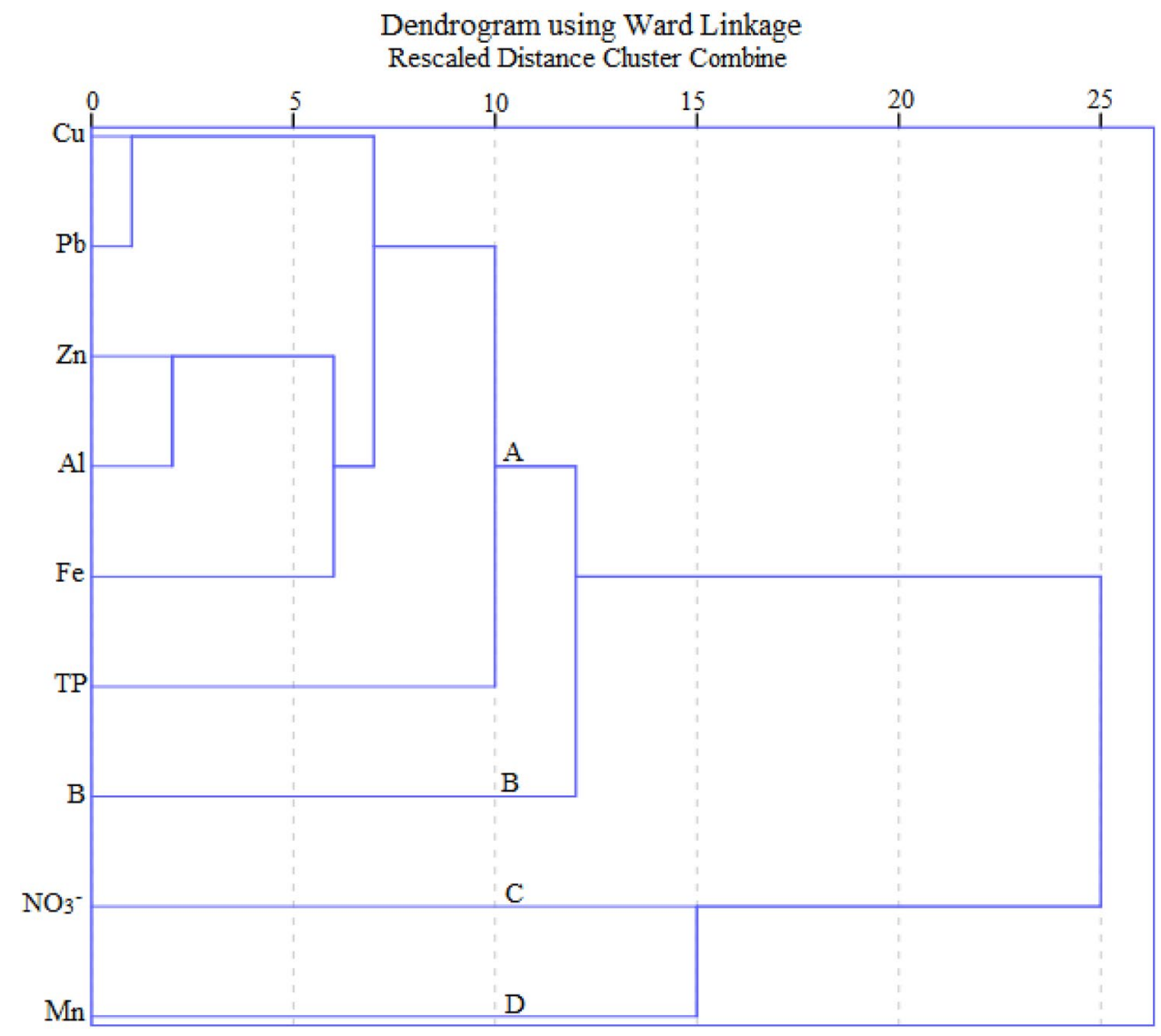

cleaning motor bikes on the river banks were observed to pollute the river with $\mathrm{Mn}$. Twenty-seven and $40 \%$ of sampled sites in dry and wet seasons, respectively, had more than $0.3 \mathrm{mg} / \mathrm{L}$ concentration of Fe that is recommended by USEPA in drinking water. This is alarming bearing in mind high concentration of $\mathrm{Fe}$ in drinking water is associated with cancer and majority of residents within Ewaso Nyiro ecosystem use its water without any form of treatment. Proper agronomic practices should be encouraged to curb Mn and Co pollution besides introduction of macrophytes such as Cyperus articulatus and Typha latifolia in Ewaso Nyiro ecosystem for Fe and Al phytoremediation, respectively.

Acknowledgments This project was supported by Sino-Africa Joint Research Center (Number: SAJC201601), Chinese Academy of Sciences and National Natural Sciences of China, (Number: NSFC 31361140360).

Author contributions $X Y$ had the original idea for the study. RG assisted in research permit acquisition. $\mathrm{KG}$ and JO collected samples, while SN prepared the manuscript. All authors have read and approved the final manuscript.

Availability of data and materials Data have been shared.

\section{Compliance with ethical standards}

Conflict of interest The authors declare that they have no conflict of interest.

Open Access This article is licensed under a Creative Commons Attribution 4.0 International License, which permits use, sharing, adaptation, distribution and reproduction in any medium or format, as long as you give appropriate credit to the original author(s) and the source, provide a link to the Creative Commons licence, and indicate if changes were made. The images or other third party material in this article are included in the article's Creative Commons licence, unless indicated otherwise in a credit line to the material. If material is not included in the article's Creative Commons licence and your intended use is not permitted by statutory regulation or exceeds the permitted use, you will need to obtain permission directly from the copyright holder. To view a copy of this licence, visit http://creativecommons .org/licenses/by/4.0/.

\section{References}

1. Almer C, Laurent-Lucchetti J, Oechslin M (2017) Water scarcity and rioting: disaggregated evidence from Sub-Saharan Africa. J Environ Econ Manag 86:193-209

2. Bala M, Shehu R, Lawal M (2010) Determination of the level of some heavy metals in water collected from two pollutionprone irrigation areas around Kano Metropolis. Bayero J Pure Appl Sci 1(1):36-38 
3. Ben Salem Z, Capelli N, Laffray X, Elise G, Ayadi H, Aleya L (2014) Seasonal variation of heavy metals in water, sediment and roach tissues in a landfill draining system pond (Etueffont, France). Ecol Eng 69:25-37

4. Chouchane $\mathrm{H}$, Krol MS, Hoekstra AY (2018) Expected increase in staple crop imports in water-scarce countries in 2050. Water Res $X$ 1:100001

5. Cobbina SJ, Agoboh YP, Duwiejuah AB, Bakobie N (2015) Evaluation of stored rainwater quality in Basic Schools in the Tamale Metropolis, Ghana. Water Qual Exp Heal 7:4

6. Davies W, Gustafsson J (2015) Water Resources in Kenya: Closing the Gap (Report)

7. Defarge N, Vendômois JS, Séralini GE (2018) Toxicity of formulants and heavy metals in glyphosate-based herbicides and other pesticides. Toxicol Rep 5:156-163

8. De Leeuw J, Said MY, Kifugo S, Musyimi Z, Mutiga JK, Peden D (2012) Benefits of riverine water discharge into the Lorian Swamp, Kenya. Water 4:1009-1024

9. Ferrante M, Signorelli SS, Ferlito SL, Grasso A, Dimartino A, Copat $C$ (2018) Groundwater-based water wells characterization from Guinea Bissau (Western Africa): a risk evaluation for the local population. Sci Total Environ 620:916-926

10. Gao L, Li S, Wang Z, Liang Z, Chen J, Liang B (2018) Contamination, potential mobility, and origins of lead in sediment cores from the Shima River, south China. Environ Pollut 242:1128-1136

11. Geology and mineral resource potential of Kenya (2015)

12. Giné GR, Pérez A (2013) Unravelling the linkages between water, sanitation, hygiene and rural poverty: the wash poverty Index. Water Res Mant 27:1501-1515

13. Gordon B, Callan P, Vickers C (2008) WHO guidelines for drinkingwater quality. WHO Chronicle 38:564

14. Goulet RR, Lalonde JD, Munger C, Dupuis S (2005) Phytoremediation of effluents from aluminum smelters: a study of $\mathrm{Al}$ retention in mesocosms containing aquatic plants. Water Res 39:2291-2300

15. Guan Q, Cai A, Wang F, Wang L, Wu T, Pan B, Lu M (2016) Heavy metals in the riverbed surface sediment of the Yellow River, China. Environ Sci Pollut Res 23:24768-24780

16. International atomic energy agency bulletin (2011) All about water

17. Khan K, Wasserman GA, Liu X, Ahmed E, Parvez F, Slavkovich V, Factor-Litvak $P$ (2012) Manganese exposure from drinking water and children's academic achievement. Neurotoxicol 33:91-97

18. Khan S, JehanRehmanShahDin SMNSMTI (2013) Drinking water quality and human health risk in Charsadda district, Pakistan. J Clean Prod 60:93-101

19. Krhoda G (2006) Kenya National Water Development Report

20. Land use in Kenya (2014) The case for a national land use policy

21. Laikipia County Integrated Plan (2017)

22. Lanari AN, Schuler R, Kohler T, Liniger H, Lanari N, Schuler R, Liniger $\mathrm{H}$ (2019) The impact of commercial horticulture on river water resources in the Upper Ewaso Ngiro River. BioOne Complete 38:114-124

23. Liu Y, Wang Q, Zhuang W, Yuan Y, Yuan Y, Jiao K, Chen Q (2018) Calculation of Thallium's toxicity coefficient in the evaluation of potential ecological risk index: a case study. Chemos 194:562-569

24. Makokha VA, Qi Y, Shen Y, Wang J (2016) Concentrations, distribution, and ecological risk assessment of heavy metals in the East Dongting and Honghu Lake, China. Exp Health 8:31-41

25. Marshall S (2011) The water crisis in Kenya: causes, effects and solutions. Glob Major E J 2:4-18

26. Ministry of Health, Kenya. National Cancer Control Strategy 2017-2022
27. Muzerengi $C$ (2013) Enrichment and geoaccumulation of $\mathrm{Pb}$, $\mathrm{Zn}, \mathrm{As}, \mathrm{Cd}$ and $\mathrm{Cr}$ in soils near New Union Gold Mine, Limpopo Province of South Africa. Mine Water Circ Econ 14:720-727

28. Mwangi JK, Thiong GT, Gathenya JM (2010) Assessment of the water quality status of sasumua watershed, Kenya (Report)

29. Naimi-Ait-Aoudia M, Berezowska-Azzag E (2014) Algiers carrying capacity with respect to per capita domestic water use. Sustain Cites Soc 13:1-11

30. Naito W, Kamo M, Tsushima K, Iwasaki Y (2010) Exposure and risk assessment of zinc in Japanese surface waters. Sci Total Environ 408:4271-4284

31. Njuguna SM, Onyango JA, Githaiga KB, Gituru RW, Yan X (2020) Application of multivariate statistical analysis and water quality index in health risk assessment by domestic use of river water. Case study of Tana River in Kenya. Process Saf Environ Protec 133:149-158

32. Njuguna SM, Makokha VA, Yan X, Gituru RW, Wang Q, Wang J (2019) Health risk assessment by consumption of vegetables irrigated with reclaimed waste water: a case study in Thika (Kenya). J Environ Manag 231:576-581

33. Njuguna SM, Yan X, Gituru RW, Wang Q, Wang J (2017) Assessment of macrophyte, heavy metal, and nutrient concentrations in the water of the Nairobi River Kenya. Environ Monit Assess 189:454

34. Nyingi DW, Gichuki N, Ogada MO (2013) Freshwater ecology of Kenyan highlands and lowlands. Dev Earth Sur Proc 16:199-218

35. Ochieng EZ, Lalah JO, Wandiga SO (2007) Analysis of heavy metals in water and surface sediment in five Rift Valley lakes in Kenya for assessment of recent increase in anthropogenic activities. Bull Environ Contam Toxicol 79:570-576

36. Ogendi GM, Ong'oa IM (2009) Water policy accessibility and water ethics in Kenya. Santa Clara J Intern Law 1:177-196

37. Rahman MM, Islam MA, Bodrud-Doza M, Muhib MI, Zahid A, Shammi M, Kurasaki M (2018) Spatio-temporal assessment of groundwater quality and human health risk: a case study in Gopalganj, Bangladesh. Exp Health 10:167-188

38. Rieuwerts JS (2007) The mobility and bioavailability of trace metals in tropical soils: a review. Chem Speciat Bioavailab 19(2):75-85

39. Saleem M, Iqbal J, Shah MH (2019) Seasonal variations, risk assessment and multivariate analysis of trace metals in the freshwater reservoirs of Pakistan. Chemos 216:715-724

40. Sharifi Z, Hossaini SMT, Renella G (2016) Risk assessment for sediment and stream water polluted by heavy metals released by a municipal solid waste composting plant. J Geochem Explor J 169:202-210

41. Simeon L, Gideon N (2019) Water resources access, use and management in the upper Ewaso Nyiro, North River sub-basin of Kenya. Int Acad J Soc Sci Educ 2:26-41

42. Sun $X$, Fan D, Liu M, Tian Y, Pang Y, Liao H (2018) Source identification, geochemical normalization and influence factors of heavy metals in Yangtze River Estuary sediment. Environ Pollut 241:938-949

43. Udechukwu BE, Ismail A, Zulkifli SZ, Omar H (2015) Distribution, mobility, and pollution assessment of $\mathrm{Cd}, \mathrm{Cu}, \mathrm{Ni}, \mathrm{Pb}, \mathrm{Zn}$, and $\mathrm{Fe}$ in intertidal surface sediments of $\mathrm{Sg}$. Puloh mangrove estuary Malaysia. Environ Sci Pollut Res 22:4242-4255

44. US Environmental Protection Agency (2012) Watershed Assessment, Tracking \& Environmental Results

45. WHO Regional Office for Europe, Copenhagen, Denmark (2001) Air quality guidelines-second edition

46. Xiong Q, Zhao W, Zhao J, Zhao W, Jiang L (2017) Concentration levels, pollution characteristics and potential ecological risk of dust heavy metals in the metropolitan area of Beijing, China. Int J Environ Res Public Health 14:1159 
47. Xu G, Liu J, Pei S, Gao M, Hu G, Kong X (2015) Sediment properties and trace metal pollution assessment in surface sediments of the Laizhou Bay, China. Environ Sci Pollut Res 22:11634-11647

48. Yang Y, Wei L, Cui L, Zhang M, Jun W (2017) Profiles and risk assessment of heavy metals in Great Rift Lakes. Kenya, Chemos, p 45

49. You L, Xie H, Wood-Sichra U, Guo Z, Wang L (2014) Irrigation potential and investment return in Kenya. Food Policy 47:34-45

50. Zeng X, Liu Y, You S, Zeng G, Tan X, Hu X, Li F (2015) Spatial distribution, health risk assessment and statistical source identification of the trace elements in surface water from the Xiangjiang River, China. Environ Sci Pollut Res 22:9400-9412

51. Zhao L, Mi D, Chen Y, Wang L, Sun Y (2015) Ecological risk assessment and sources of heavy metals in sediment from Daling River basin. Environ Sci Pollut Res 22:5975-5984

Publisher's Note Springer Nature remains neutral with regard to jurisdictional claims in published maps and institutional affiliations. 